\title{
How to Build Word of Mouth: The Role Brand Personality, Brand Love and Brand Loyalty
}

\author{
Meiske $^{1}$, Tengku Ezni Balqiah ${ }^{2}$ \\ ${ }^{1,2}$ Magister of Management, Faculty of Economics and Business, University of Indonesia, \\ Indonesia \\ ${ }^{1}$ meiske_tenjune@yahoo.com
}

\begin{abstract}
This research empirically tests the impact of five brand personality dimensions (sincerity, excitement, competence, sophistication and ruggedness) on brand love, store brand loyalty and positive word of mouth. We focused on online retailers in Indonesia. The proposed model is tested using structural equation modeling (SEM) from 398 collected respondents. +WOM is important to reduce marketing costs. The purpose of this study is to analyze whether the five dimensions of brand personality and brand love have a positive impact on store brand loyalty and positive word of mouth. The results demonstrated that three of five dimensions of brand personality namely 'sincerity', 'competence' and 'sophistication' have a positive impact on brand love and a mediated through store brand loyalty path to positive word of mouth. The effect of two dimensions brand personality on +WOM because brand love. So, this finding reinforces the importance of the brand love and brand personality construct to retail business.
\end{abstract}

Keywords: Word of Mouth, Brand Personality, Brand Love, Sincerity, Excitement, Competence, Sophistication, Ruggedness, Brand Loyalty.

\section{Introduction}

As a result of a survey conducted by the Indonesian Internet Service Provider Association, the growth of internet users from year to year experienced growth. In 2017 internet user penetration amounted to 143.26 millions of Indonesia's total population of 262 million people, namely 54.68 percent [1]. According to the internet usage data in the economic field, namely selling online at 16.83 percent, banking transactions at 17.04 percent, looking for employment at 26.19 percent, buying online at 32.19 percent, information buying 37.82 percent, helping jobs at 41.04 percent, and find a price of 45.14 percent. Related to the economic growth of the last 3 years that continues to experience growth, Gross Domestic Product in 2015 at 4.79 percent, in 2016 experienced a growth of 4.94 percent and in 2017 it reached 5.19 percent. This is a great opportunity for online retail entrepreneurs to develop online businesses [1].

The relationship between loyalty and profitability that has been studied theoretically stated that there is an important relationship, that is, i.e., developing and maintaining customer loyalty can affect the profitability of the company [2]. The study states that customer loyalty can affect profitability by increasing sales per customer and can reduce marketing costs [3]. 
Reduction in marketing costs can occur with the reason that the cost to maintain customer loyalty is less when compared to the cost of acquiring new customers. Customers can be said to be loyal not only by making repeat purchases but also actively involved in positive WOM towards the company [4].

The concept of branding in retail research has grown from "product as a brand" to "shop as a brand" (store brand), and then to "retailer as a brand" (retail brand) [5]. Furthermore, information technology that has experienced high progress has formed online retail (e-tailing) [6].

Consumers who have a love for a particular website / online store tend to buy substitute items if the items they are looking for are missing. This is what we can interpret as consumer loyalty. Consumer relations with brands that are built can affect the level of patronage and loyalty [7]

Previous research said that Positive Word of Mouth and Brand Loyalty could be generated from Brand Love [8]. Brand love is a relatively new conceptualization, has been considered as an antecedent of the desired post-purchase parameters such as positive word of mouth (+ WOM), brand loyalty, and active involvement [8], [9]. Brand love is also defined as the level of passionate, emotional attachment that consumers are satisfied with certain trade names [8].

\section{Literature Review}

\subsection{Positive Word of Mouth (+WOM)}

WOM is offline, and e-WOM is conceptualized as a consequence of brand love [8], [10]. Positive and negative statements made by customers either through offline or online channels can be understood as Word of Mouth (WOM).

There is a difference between offline and online eWOM; the difference is that offline WOM occurs more in the form of one-to-one, mostly spoken while e-WOM mostly occurs from written communication, and occurs in the form of one-to-one, one-to-many or manytomany. E-WOM is more open to the ripple effect, and the control is easier for the company to do compared to offline WOM. In this research, the definition of Positive Word of Mouth is a good relation can provide a foundation for customers to communicate positive aspects of the brand to others.

\subsection{Brand Personality}

Brand personality is often used to measure intangible asset associations, proven to have benefits for academics and practitioners in explaining the consequences of the brand association [11].

The following are references in previous brand personality research called the Big 5 [12]. Identifies five dimensions of brand personality, namely sincerity, excitement, competence, sophistication, and ruggedness [12]. Sincerity is explained as an attribute that is simple, real and honest. Excitement is explained as an interesting, bold, imaginative and contemporary attribute. Competence is explained as a reliable, intelligent, safe and confident attribute. Sophistication is described as a glamorous, upscale, good-looking, and charming attribute. Ruggedness is explained as a hard, outdoorsy, and masculine attribute. This construct is defined as "the set of human characteristics associated with the brand".

There are only three comparable five-scale Aaker dimensions in the Big 5 namely (sincerity with agreeableness, excitement with extraversion, and competence with conscientiousness [12]. There are only three general dimensions, namely sincerity, excitement and sophistication that are universally relevant and generic for studies in Japan, Spain and the 
United States [13]. In this study, the dimensions used are the five dimensions in order to learn the brand personality as a whole. In this research, the definition of brand personality is the human characteristics that have a relation to the brand.

\subsection{Brand Love}

Brand management considers brand love as one of the main goals because it is considered the most emotional relationship of consumer-brand relationships [14]. Consumer-brand relationship is a major change that occurs from transactional to relationship in the marketing paradigm [7].

Previous research states that there are several factors that makeup brand love. Involvement can function as a moderator [15]. Attitudes have a great effect on brand love, while affordability has little effect on brand love. Brand love for high-involved consumers is facilitated by subjective norms, while for consumers who are involved low the tendency of anthropomorphism will have a higher effect.

In some previous studies shows that brand love can truly be experienced by consumers [8], [10]. According to [7], [8], [10] many benefits resulting from consumer love for the brand, brand love can produce positive word of mouth, brand loyalty, an increase in the desire to pay premium prices. In this research, a definition of brand love is the emotionally bound and passionate level is found in the basic consumers of a particular trade name.

\subsection{Store Brand Loyalty}

Customer loyalty is related to internet shopping experience, this finding is consistent with several other studies which show that prices do not significantly influence online buyers and are more inclined to comfort [16].

In the loyalty literature, customer loyalty has two components, namely behavior and attitude [17]), which means repeated buying behavior can have a positive impact on the business. Consistent with other studies, loyalty does not only require repeated purchases but is positive about the company [4].

One of the goals of retailers is to have loyal customers. Customer satisfaction produces loyalty [18]. One important trend is the emergence of retailers as brands [19]. The company's reputation with a strong store image has its advantages which have an impact on customer satisfaction that produces store loyalty. In this research, the definition of store brand loyalty is the extent of consumer commitment to a brand [20].

\section{Method}

\subsection{Hypothesis Development}

The researcher tried to make a conceptual model regarding the relationship of the 5 dimensions of Brand Personality that could influence brand love, store brand loyalty and + WOM.

The figure below shows the conceptual model of research. 


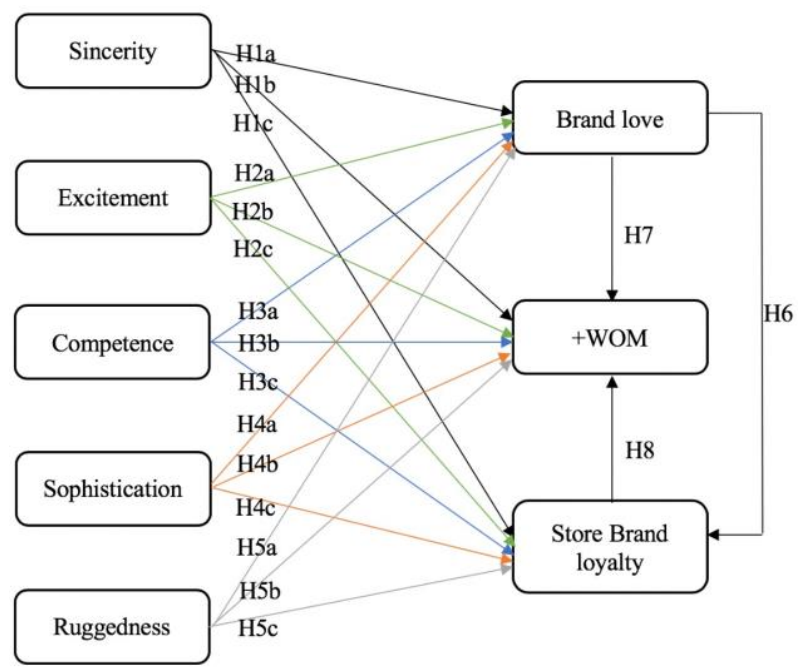

Fig. 1. Conceptual model.

The conceptual model described above is intended to explain that Brand Personality has five dimensions, namely sincerity, excitement, competence, sophistication, ruggedness as Independent Variables and brand love, +WOM, store brand loyalty as Dependent Variable. Most of the research related to brand love found brand loyalty and + WOM as a result of brand love [8].

In connection with the conceptual model of the study, this study will test 18 hypotheses. The following are the research hypotheses:

H1a: Sincerity positively affects Brand Love.

H1b: Sincerity positively affects + WOM.

H1c: Sincerity positively affects Store Brand Loyalty.

H2a: Excitement positively affects Brand Love.

$\mathrm{H} 2 \mathrm{~b}$ : Excitement positively affects + WOM.

H2c: Excitement positively affects Store Brand Loyalty.

H3a: Competence positively affects Brand Love.

H3b: Competence positively affects + WOM.

$\mathrm{H} 3 \mathrm{c}$ : Competence positively affects Store Brand Loyalty.

H4a: Sophistication positively affects Brand Love.

H4b: Sophistication positively affects + WOM. H4c: Sophistication positively affects Store Brand Loyalty.

H5a: Ruggedness positively affects Brand Love.

H5b: Ruggedness positively affects + WOM.

H5c: Ruggedness positively affects Store Brand Loyalty.

H6: Brand love positively affects Store Brand Loyalty.

H7: Brand love positively affects + WOM (Word of Mouth).

H8: Store brand loyalty affects + WOM (Word of Mouth).

\subsection{Methodology}

The method used to process the collected data is the Structural Equation Modeling (SEM) method with the Lisrel 8.70 program. In this research, to calculate each measurement model construct with factor analysis to measure each research construct by looking at indicators that 
can be used. To see the compatibility and suitability of the results obtained in the previous stage, namely by using Confirmatory Factor Analysis. The significance in this study is TValue $\geq 1.64$.

\subsection{Measures and Instrument Design}

In this study researchers used brand personalities from [12] as part of a large brand research. For brand love, researchers use a scale version of Roy et al. (2016) that adapted from [8]. Including two reasons in this election, the first was quite comprehensive in its investigation. Both [8] use brand loyalty constructs and + WOM in their research studies, which can be adjusted.

The item used as a store brand loyalty scale, researchers adapted from [21], as it was launched in Table 1. For + WOM using several versions adapted by [21] that adapted from [22].

The questionnaire question used by the researcher was a Likert scale in five level. Strength on a Likert scale is a questionnaire that is easily shared and understood [23]. The researcher designed a questionnaire given to respondents to meet the information needs needed. The questionnaire was compiled using a Likert scale structured question which had a very agreeable scale of choice until the scale strongly disagreed. Likert scale consisting of five points, ranging from "Strongly agree" to Strongly disagree".

To direct respondents to provide answers by choosing alternative answers provided, making it easier for respondents. The form of the question used is an open question. Survey and data collection questionnaire consist of five parts, namely: "Brand love", "Store Brand loyalty", "Positive word of mouth", "Brand Personality", "Demography".

The method used in this study uses Maximum

Likelihood. The lowest ratio of 5 respondents observed with a normal distribution where a latent variable has several indicators. Indicators in the study amounted to $44 \mathrm{x} 5=220$ [24]. So, the number of samples taken in this study at least 220 respondents. The number of respondents in this study were 398 respondents.

\subsection{Results: Hypotheses testing using SEM}

In order to test reliability and validity, the hypothesis shown in Figure 1 using SEM. The results of the analysis reported in Table 1 fit models are acceptable (CFI=0.99; GFI $=0.87$ RMSEA=0.053; SRMR $=0.043$ ).

Table 1. Result Pretest of hypothesis tests

\begin{tabular}{|c|c|c|c|c|}
\hline Hypothesis & Structural Path & $\begin{array}{c}\text { Std. } \\
\text { estimation }\end{array}$ & T-Value & Results \\
\hline $\mathrm{H} 1 \mathrm{a}$ & $\begin{array}{c}\text { Sincerity } \rightarrow \text { Brand } \\
\text { Love }\end{array}$ & 0.29 & 2.85 & $\begin{array}{c}\text { Hypothesis H1a is } \\
\text { accepted. }\end{array}$ \\
\hline $\mathrm{H} 1 \mathrm{~b}$ & Sincerity $\rightarrow+$ WOM & 0.19 & 1.99 & $\begin{array}{c}\text { Hypothesis H1b is } \\
\text { accepted. }\end{array}$ \\
\hline $\mathrm{H} 1 \mathrm{c}$ & $\begin{array}{c}\text { Sincerity } \rightarrow \text { Store Brand } \\
\text { Loyalty }\end{array}$ & -0.055 & -0.54 & $\begin{array}{c}\text { Hypothesis H1c is } \\
\text { rejected. }\end{array}$ \\
\hline $\mathrm{H} 2 \mathrm{a}$ & Excitement $\rightarrow$ Brand Love & -0.15 & -1.18 & $\begin{array}{c}\text { Hypothesis H2a is } \\
\text { rejected. }\end{array}$ \\
\hline
\end{tabular}




\begin{tabular}{|c|c|c|c|c|}
\hline $\mathrm{H} 2 \mathrm{~b}$ & Excitement $\rightarrow+$ WOM & 0.20 & 1.79 & $\begin{array}{l}\text { Hypothesis } \mathrm{H} 2 \mathrm{~b} \text { is } \\
\text { accepted. }\end{array}$ \\
\hline $\mathrm{H} 2 \mathrm{c}$ & $\begin{array}{l}\text { Excitement } \rightarrow \text { Store } \\
\text { Brand Loyalty }\end{array}$ & -0.056 & -0.45 & $\begin{array}{l}\text { Hypothesis } \mathrm{H} 2 \mathrm{c} \text { is } \\
\text { rejected. }\end{array}$ \\
\hline $\mathrm{H} 3 \mathrm{a}$ & $\begin{array}{c}\text { Competence } \rightarrow \text { Brand } \\
\text { Love }\end{array}$ & 0.3 & 3.37 & $\begin{array}{l}\text { Hypothesis H3a is } \\
\text { accepted. }\end{array}$ \\
\hline $\mathrm{H} 3 \mathrm{~b}$ & Competence $\rightarrow+$ WOM & -0.024 & -0.28 & $\begin{array}{l}\text { Hypothesis } \mathrm{H} 3 \mathrm{~b} \text { is } \\
\text { rejected. }\end{array}$ \\
\hline $\mathrm{H} 3 \mathrm{c}$ & $\begin{array}{c}\text { Competence } \rightarrow \text { Store } \\
\text { Brand Loyalty }\end{array}$ & 0.24 & 2.7 & $\begin{array}{c}\text { Hypothesis } \mathrm{H} 3 \mathrm{c} \text { is } \\
\text { accepted. }\end{array}$ \\
\hline $\mathrm{H} 4 \mathrm{a}$ & $\begin{array}{c}\text { Sophistication } \rightarrow \text { Brand } \\
\text { Love }\end{array}$ & 0.43 & 2.97 & $\begin{array}{l}\text { Hypothesis } \mathrm{H} 4 \mathrm{a} \text { is } \\
\text { accepted. }\end{array}$ \\
\hline $\mathrm{H} 4 \mathrm{~b}$ & $\begin{array}{c}\text { Sophistication } \\
+ \text { WOM }\end{array}$ & 0.14 & 1.12 & $\begin{array}{l}\text { Hypothesis } \mathrm{H} 4 \mathrm{~b} \text { is } \\
\text { rejected. }\end{array}$ \\
\hline $\mathrm{H} 4 \mathrm{c}$ & $\begin{array}{c}\text { Sophistication } \rightarrow \text { Store } \\
\text { Brand Loyalty }\end{array}$ & 0.15 & 1.07 & $\begin{array}{c}\text { Hypothesis } \mathrm{H} 4 \mathrm{c} \text { is } \\
\text { rejected. }\end{array}$ \\
\hline H5a & $\begin{array}{l}\text { Ruggedness } \rightarrow \text { Brand } \\
\text { Love }\end{array}$ & -0.12 & -1.9 & $\begin{array}{l}\text { Hypothesis } \mathrm{H} 5 \mathrm{a} \text { is } \\
\text { rejected. }\end{array}$ \\
\hline $\mathrm{H} 5 \mathrm{~b}$ & Ruggedness $\rightarrow+$ WOM & 0.0087 & 0.15 & $\begin{array}{l}\text { Hypothesis } \mathrm{H} 5 \mathrm{~b} \text { is } \\
\text { rejected. }\end{array}$ \\
\hline $\mathrm{H} 5 \mathrm{c}$ & $\begin{array}{c}\text { Ruggedness } \rightarrow \text { Store } \\
\text { Brand Loyalty } \\
\end{array}$ & 0.061 & 0.96 & $\begin{array}{l}\text { Hypothesis } \mathrm{H} 5 \mathrm{c} \text { is } \\
\text { rejected. }\end{array}$ \\
\hline H6 & $\begin{array}{l}\text { Brand Love } \rightarrow \text { Store } \\
\text { Brand Loyalty }\end{array}$ & 0.51 & 7.37 & $\begin{array}{l}\text { Hypothesis H6 is } \\
\text { accepted. }\end{array}$ \\
\hline H7 & Brand Love $\rightarrow+$ WOM & 0.16 & 2.5 & $\begin{array}{l}\text { Hypothesis H7 is } \\
\text { accepted. }\end{array}$ \\
\hline H8 & $\begin{array}{c}\text { Store Brand Loyalty } \rightarrow \\
+ \text { WOM }\end{array}$ & 0.24 & 3.77 & $\begin{array}{l}\text { Hypothesis H8 is } \\
\text { accepted. }\end{array}$ \\
\hline
\end{tabular}

\section{Discussion}

This study extends the application of brand personality and brand love to the online retail context and extents about the understanding of the 'brand love' and 'brand personality' construct. The first result in this study is to show that brand love can directly and indirectly positively effects to +WOM.

The second result, dimension of brand personality, namely sincerity, competence and sophistication have a positive effect on brand love, through brand store loyalty leads to +WOM. This shows that all three brand personality dimensions can have a positive effect on + WOM because of brand love. So, it is important to build brand love in retail businesses.

The third result is the brand personality dimension, namely sincerity and excitement, has a positive effect on + WOM directly. So that it can be concluded the importance of building a brand personality in the retail industry. This study shows that the brand personality dimension 
can influence brand love, so it is important to be able to build a brand personality on a brand, related to the hedonic feeling that arises from the online shopping experience that consumers have so that it can lead to brand love.

This study tries to provide a basis for advancing the literature of 'positive word of mouth'. This study tries to provide a basis for advancing the literature of 'positive word of mouth'. Studies related to positive word of mouth have shown that store brand loyalty can build positive word of mouth [21]. The main theoretical implication of this research is the formation of a relationship between the two dimensions of brand personality and brand love. This extends the literature continued by Roy et al., (2016) which makes a call to test brand personality as an antecedent for brand love.

The results in this study indicate that the two dimensions of personality help in building positive word of mouth by passing path store loyalty to path to +WOM. However, the results also show that the presence of positive personality dimensions is not enough to produce $+\mathrm{WOM}$ and store brand loyalty directly. So that the presence of brand love is also needed in producing + WOM. Therefore, the desired parameters of consumer behavior can be influenced not only by developing a positive brand personality but also by equipping with the generation of emotions such as love of the brand.

\subsection{Implication}

The key managerial insight is that the dimensions of sincerity, competence and sophistication of brand personality are antecedents to brand love [21]. Previous studies have shown that brand relationships have used brand personality as a managerial tool [25]. This study studied five dimensions of brand personality, there are three dimensions that influence brand love, so the use of brand personalities is stronger because it demonstrates that the dimensions of brand personality are used to develop strong love-like relationships with customers. The store retailers can precisely project the personality of existing market leader retailers. This study suggests from the results of this fact, it is good for managers of online retail store brands to properly manage projectable personalities in order to achieve their business goals [26]. The finding of this study is the five brand personality dimensions given by [12] ruggedness do not affect positively to word of mouth, store brand loyalty and brand personality. The limitation of this study is the interpretation of indicator words from dimensions brand personality varies for each culture in each country. So, respondent has difficulty to understand the translation words in the dimensions of brand personality. Despite the fact that the interpretation of dimensional indicator words from brand personality varies among cultures in each country. Future studies should try to overcome this limitation by providing another indicator word that can be interpreted in the culture of each country to be studied.

\section{References}

[1] A.P.J.I.I., “Asosiasi Penyelenggara Jasa Internet Indonesia.” .

[2] R. L. Oliver, "Whence Consumer," Loyalty, vol. 63, no. 1999, pp. 33-44.

[3] L. L. Berry, "Relationship Marketing of Services -," Grow. Interes. Emerg. Perspect.

[4] T. Reya, S. J. Morrison, M. F. Clarke, and I. L. Weissman, "Stem cells, cancer, and cancer stem cells," Nature, vol. 414, p. 105.

[5] S. Burt and K. Davies, "From the retail brand to the retailer as a brand: Themes and issues in retail branding research," Int. J. Retail Distrib. Manag., vol. 38, no. 11, pp. 865-878.

[6] A. Kennedy and J. Coughlan, "Online shopping portals: An option for traditional 
retailers?," Int. J. Retail Distrib. Manag., vol. 34, no. 7, pp. 516-528.

[7] S. Fournier, "Consumers and Their." Brands.

[8] B. A. Carroll and A. C. Ahuvia, "Some antecedents and outcomes of brand love.".

[9] L. Bergkvist and T. Larsen, "Two studies of consequences and actionable antecedents of brand love," J. Brand Manag., vol. 17, no. 7, p. 504.

[10] R. Batra, A. Ahuvia, and R. P. Bagozzi, "Brand Love,” J. Mark., vol. 76, pp. 1-16.

[11] M. Eisend and N. E. Sauer, "Brand personality: A meta-analytic review of antecedents and consequences," Mark. Lett., vol. 24, no. 3, pp. 205-216.

[12] Aaker, "Dimensions of brand personality." .

[13] D. A. Aaker and R. Jacobson, No Title. The Value.

[14] T. Langner, D. Bruns, A. Fischer, and J. R. Rossiter, "Falling in love with brands : a dynamic analysis of the trajectories of brand love." pp. 15-26.

[15] S. M. Hegner, A. Fenko, and A. Teravest, "Using the theory of planned behaviour to understand brand love," J. Prod. Brand Manag., vol. 26, no. 1, pp. 26-41.

[16] C. Abramson, R. L. Andrews, I. S. Currim, and M. Jones, "Parameter.".

[17] K. L. Keller, "Conceptualizing, Measuring, Managing Customer-Based Brand Equity," J. Mark., vol. 57, no. 1, pp. 1-22.

[18] R. L. Oliver, R. T. Rust, and S. Varki, "Customer Deli \& t: Managerial Ir \& ght Foundations," J. Retail., vol. 73, no. 3, p. 336.

[19] D. Grewal, G. R. Iyer, and M. Levy, "Internet retailing: Enablers, limiters and market consequences," J. Bus. Res., vol. 57, no. 7, pp. 703-713.

[20] M. L. Barnett, J. M. Jermier, and B. A. Lafferty, "Corporate Reputation," Defin. Landsc., vol. 9, no. 1, pp. 26-39.

[21] P. Roy, K. Khandeparkar, and M. Motiani, "A lovable personality: The effect of brand personality on brand love,” J. Brand Manag., vol. 23, no. 5, pp. 97-113.

[22] D. D. Gremler and K. P. Gwinner, "CustomerEmployee Rapport in Service Relationships.”.

[23] N. K. Malhotra, Marketing Research an Applied Orientation, 6th ed. Pearson/Prentice Hall.

[24] P. M. Bentler and C.-P. Chou, "No Title," in Practical Issues in, .

[25] M. Blackston, "No Title," J. Advert. Res.

[26] J. Zentes, D. Morschett, and H. Schramm-Klein, "Brand personality of retailers - an analysis of its applicability and its effect on store loyalty," Int. Rev. Retail. Distrib. Consum. Res., vol. 18, no. 2, pp. 167-184. 